\title{
EMPATHY AND VICARIOUSNESS OF AUTOBIOGRAPHICAL MEMORIES IN THE CHINESE SAMPLE ${ }^{1}$
}

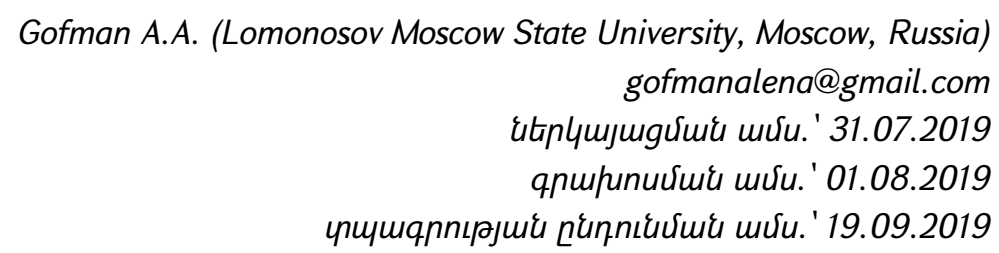

There is empirical evidence suggesting that autobiographical memories of similar experiences evoke empathy $[1,6]$. The positive correlation between trait empathy and phenomenology of autobiographical memories was also demonstrated [9]. We assumed that not all autobiographical memories are relevant to empathic feeling. The most promising candidate for scaffolding impact onto empathy, in our point of view, is a specific type of memories vicarious memories. 96 Chinese participants filled out an Interpersonal Reactivity Index questionnaire and drew their lifelines of the most important events from their childhood in correlation in the timeline. Lifelines were analyzed in regard to the proportion of other-focused and vicarious memories and their emotional valence. The study suggests that the significant predictor of empathy is the distinctive type of childhood memories with specific level of vicariousness. The main focus in these autobiographical memories is shifted to the other person who is active toward the participant.

Keywords: autobiographical memory, empathy, vicarious memories, lifeline.

The modern literature of autobiographical memory suggests that autobiographical memories of similar experiences evoke empathy $[1,2,6]$. The positive correlation between trait empathy and phenomenology of autobiographical memories was also demonstrated [9]. Bluck S. and her colleague showed in their research that empathy levels for a person experiencing chronic pain appear to increase after sharing painrelated autobiographical memories [2].

Although the debate continues over the specific processes involved in empathy, it has been defined as "the action of understanding, being aware of, being sensitive to, and vicariously experiencing the feelings, thoughts, and experience of another (person)" [7]. According to this statement, we considered vicarious autobiographical memories as the most relevant kind of autobiographical memories to empathy. Current literature has suggested that people not only have vivid memories of their own personal experiences, but also vicarious memories of events that happened to other people [8].

Although a recent attempt to research a direct relationship between the consistency of a vicarious life story of an important other and empathy did not reveal a

1 The research was supported by RFBF (project No. 19-013-00387) 
correlation [5], we assumed that there could be several explanations of this result. Firstly, in our opinion, the number of spontaneously recalled vicarious memories, their emotional valence, the assignment of memories to certain age periods and life themes could be more diagnostic as independent variable. Secondly, we associate the lack of correlation between empathy and vicarious component of memories in the limitations of the narrative format data, which reduces the amount of spontaneously recalled memories and provokes their thematic selection. The main aims of this study were: firstly, to examine variables related to self-focused, other-focused, and vicarious autobiographical memory in regard to the trait empathy (as measured by Interpersonal Reactivity Index) and differentiate participants' memories according to the level of a vicarious component. Secondly, to specify the characteristics of vicarious autobiographical memories (number of the memories, their emotional valence, the assignment of memories to certain age periods and life topics, etc.), related to empathy.

\section{Method}

Participants: 96 Chinese participants (age 20-32, 60 female) took part in the current study.

Procedure: All participants were asked to draw their lifelines of the most memorable and important events from their personal past and childhood with respect to the timeline. The instruction: of lifeline method reads as follows: "Consider this paper as representing your childhood, recall the most memorable events from your childhood, locate them with respect to the timeline, give brief titles, put the age, and indicate the valence and intensity of the emotions associated with each recalled event by distance from the arrow to the top (positive) or to the bottom (negative)". In addition to the life line method participants also completed Chinese adaptation (C-IRI) [10] of Interpersonal Reactivity Index [3, 4]. The 22-item C-IRI is a self-reported questionnaire consisting of four subscales, including Fantasy Scale, Empathy Scale, and Personal Distress Scale. Participants are requested to indicate the degree to which each item describes them using a 5-point Like-type scale, which varied from 0 (does not describe me well) to 4 (describes me very well). A higher score in a subscale represents a higher functioning in each aspect of empathy.

C-IRI is based on the idea of the multidimensional nature of empathy which suggested that a need to assess the tendency to fantasize as well as personal distress in addition to empathy.

Considering previous findings we considered the following scales as more appropriate to the current study.

Empathy Scale. The empathic scale assesses the tendency to experience feelings of sympathy and compassion for unfortunate others. Examples: "I often have tender, concerned feelings for people less fortunate than me." "When I see someone being taken advantage of, I feel kind of protective toward them." "Other people's misfortunes do not usually disturb me a great deal (-)." 
Fantasy Scale. The fantasy scale measures the tendency to imaginatively transpose oneself into fictional situations. Examples: "I really get involved with the feelings of the characters in a novel." "After seeing a play or movie, I have felt as though I were one of the characters." "When I am reading an interesting story or novel, I imagine how I would feel if the events in the story were happening to me"

As we noted above in the recent studies authors considered vicarious memories, i.e. memories of events that happened to other people perceived as a valuable part of one's own life [8] and not vicarious ones.

In the current study, all memories are distinguished according to the vicariousness in respect to 4-point scale, where:

0 - is considered as self-focused memories, with no other persons present in memory narrative ("I visited Moscow for the first time")

1 - is considered as self-focused memories, where another person is assumed to be present in the situation, but not specified ("I met a new friend").

2 - is considered as other-focused memories, related to self ("My mother presented me a doll”), or “we-memories” type, where participant didn't distinguish themselves and important other ("We were eating ice-cream and laughing")

3 - is considered as other-focused memories, totally independent of self ("My grandmother moved to another city").

Results: The total number of all recalled memories was 633 (369 positive and 264 negative), 378 of them were considered as vicarious memories. The decisions about the level of vicariousness were made by two experts. Regression analysis was performed to determine the relationship between empathy score and other factors. The research reveals a connection between the level of empathy and autobiographical memory. The findings highlight the fact that positive vicarious autobiographical memories from childhood are significantly related to the level of empathy. Empathy score $=2.516+$ childhood positive memories (type 2$) \times 0.16, \mathrm{p}<.001 .\left[R^{2}=.227(\mathrm{~F}(1,94)=27.652, \mathrm{p}\right.$ $<.001, \beta=2.516, b=0.16, e= \pm 0.41]$.

Discussion: Although a recent attempt to identify a direct relationship between empathy and the consistency of a close other's life story surprisingly did not show correlation [5], more detailed analysis with regard to emotional valence and the certain age periods shows the abovementioned tendency to correlate. Since the content of vicarious memories is highly personally significant events about others, their use eliminates the stage of psychological linking of "one's own" and "someone else's" experience. It appears that only the childhood positive vicarious memories, involving the person himself, are related to empathy.

However, there is a need to replicate the findings obtained and to assess the generalizability of the findings in samples of different populations of participants from another cultural background with regard to cross-cultural empathy. 


\section{References}

1. Bluck S., \& Alea N. Remembering being me: The self continuity function of autobiographical memory in younger and older adults // Self continuity: Individual and collective perspectives, 2008, pp. 55-70.

2. Bluck S., Baron,J. M., Ainsworth S. A., Gesselman A. N., \& Gold K. L. Eliciting empathy for adults in chronic pain through autobiographical memory sharing // Applied Cognitive Psychology, Vol. 27, Nr. 1, 2013, pp. 81-90.

3. Davis M. H. A multidimensional approach to individual differences in empathy // JSAS Catalog of Selected Documents in Psychology, Vol. 10, 1980, pp. 85.

4. Davis M. H. Measuring individual differences in empathy: Evidence for a multidimensional approach // Journal of Personality and Social Psychology, Vol. 44, 1983, pp. 113-126.

5. Lind M., \& Thomsen D. K. Functions of personal and vicarious life stories: identity and empathy // Memory, Vol. 26(5), 2018, 672-682.

6. Mahr J. B., \& Csibra G. Why do we remember? The communicative function of episodic memory // Behavioral and brain sciences, 2018, pp. 41.

7. Merriam-Webster Incorporation. Merriam-Webster's collegiate dictionary (11th ed.). Springfield, MA: Author, 2003.

8. Pillemer D. B., Steiner K. L., Kuwabara K. J., Thomsen D. K., \& Svob C. (2015). Vicarious memories // Consciousness and Cognition, Vol. 36, 2015, pp. 233-245.

9. Pohl R. F., Bender M., \& Lachmann G. Autobiographical memory and social skills of men and women // Applied Cognitive Psychology: The Official Journal of the Society for Applied Research in Memory and Cognition, Vol. 19(6), 2005, pp. 745-759.

10. Siu A. M., \& Shek D. T. Validation of the Interpersonal Reactivity Index in a Chinese context // Research on Social Work Practice, Vol. 15, Nr. 2, 2005, pp. 118-126.

\section{ИССЛЕДОВАНИЕ ЭМПАТИИ И ВИКАРНЫХ ВОСПОМИНАНИЙ НА ВЫБОРКЕ РЕСПОНДЕНТОВ КИТАЙСКОЙ ЭТНИЧЕСКОЙ ПРИНАДЛЕЖНОСТИ}

Гофмман А.А. (Московский государственный университет имени М.В. Ломоносова, Москва, Россия)

Сегодня в ряде работ артикулируется предположение о том, что обращение к автобиографическим воспоминаниям вызывает эмпатические переживания [1, 6]. В данном исследовании разрабатывается гипотеза о взаимосвязи характеристик викарных воспоминаний - специфическом виде автобиографических 
воспоминаний, где протагонистом является не сам вспоминающий, а другие люди, и уровнем эмпатии. 96 респондентов китайской этнической принадлежности продуцировали изображение последовательности событий своего детства на линии времени с их датировкой и графическим выражением эмоциональной насыщенности, а так же заполняли опросник Межличностного Индекса Реактивности (C-IRI) [10, 3, 4]. В отличии от имеющихся на сегодняшний день исследований [8], где автобиографические воспоминания рассматриваются как викарные или не викарные, в рамках данной работы, с целью оценки викарности, все воспоминания были разделены на 4 типа по степени викарности (от 0 до 3). Результаты исследования показывают, что значимым предиктором высокого уровня эмпатии является наличие позитивных детских викарных воспоминаний, отнесенных в рамках шкалы ко второму типу. Особенностью данных воспоминаний является активность другого лица, направленная на респондента.

Ключевые слова: автобиографическая память, викарные воспоминания, эмпатия, линия жизни. 